く異なるが，静止からの出発の場合に流線が物体を離 れる点と, streak line が物体を離れる点は一致する.

（5）一定速度加ら加速される場合，流線では剝離 渦が一眭的に消えてその後は静止加らの出発のときと 同じ変化をたどるのに対して， streak line では加速 前の剝離渦惝えないまま㳄々と変形する。

（6）一般に，強い非定常運動は流れを綺麗に保つ 作用をむつ.

\section{参考文献}

1) HonjI H. \& TANEDA, S.: Unsteady flow past a circular cylinder, J. Phys. Soc, Japan, Vol, 27 (1969), pp. 1668-1677.

2) TANEDA, S. \& Hons, H.: Unsteady flow past a flat plate normal to the direction of motion, J. Phys. Soc. Japan, Vol. 30 (1971), pp. 262-272.

3) Taneda, S.: Visualization experiments on unsteady viscous flows around cylinders and plates, Presented at IUTAM Symposium on Unsteady
Boundary Layers, Laval University, May, (1971).

4）種子田定俊，天本 㹂，石井幸治：静止加ら急に一定 速度で動き出した檍円柱の揚力，九大応力研所報，符 38 号 (1972), pp. 29-35.

5) HonjI, H. \& Taneda, S.: Time-dependent flow around a circular cylinder accelerated from one steady speed to another, Rep. Res. Inst. Appl. Mech., Kyushu Univ., Vol. 17 (1969), pp. 187193.

6) TAtsuno, M. \& TAnEda. S.: Visualization of the unsteady flow past cylinders and plates decelerated from a steady speed, J. Phys. Soc. Japan, Vol. 31 (1971), pp. 1266-1274.

7) Chen, C.F. \& Christensen, D.K.: Stability of flow induced by an imulsively started rotating. cylinder, Phys, Fluids, Vol. 10 (1967), pp. 18451846.

8) Kirchner R. P. \& Chen, C. F.: Stability of timedependent rotational Couette flow, J. Fluid Mech., Vol. 40 (1970), pp. 39-47.

9) TAnedA, S: Negative Magnus effect, Rep. Res. Inst. Appl. Mech., Kyushu Univ., Vol. 5 (1957). pp. $123-128$.

\title{
円柱を過ぎる流れの剶離* Separation in a Flow Past a Circular Cylindr
}

\section{1. まえがき}

剝離の現象は，粘性流体力学の分野の中で，寒際上 重要であるにあかかわらず未だ不明な点が多く残され ている興味ある問題である。ここでは円柱を過ぎる流 れの翗離現象について述べことにするが，それに先 立ってまず一般的に㓦離の問題について考えてみよ う.

\section{1 物体形状の流体力学的分類 物体の形状は，} 流体力学的には剝離に関連して次のように分類するて よができょう。

（1）流線形物体：これは剝離を起こさない形の物 体であって，压力抵抗は小さい，例えば，翼型（小迎 角)，流れに平行な平板など.

（2）鈍い物体：これは刎離を起てすすのであっ て，圧力抵抗は大きい，てれはさらに次のように分類 される。

（a）角をもつ鈍い物体：乙の場合，流れは角加ら 剝離するので剝離点は一定である，例えば角柱や流れ

\footnotetext{
* 昭和 47 年 8 月 28 日原稿受理

** 岐阜大学工学部
}

\section{松井辰彌** \\ Tatsuya Matsur}

に垂直な平板など.

（b）角をむたない鈍い物体：乙の場合剩離点の位 置は前の場合のようにはきまらず， $R$ 数 (レイノルズ 数）に上って変わる. 例えば翼型（大迎角）や円柱な ぞ.

この最後の剥離点不定の場合が，実際上最も重要な 問題であり，また興味深い研究課題であある.

1.2 剝離の基準 剝離は，物体表面に接した境界 層内の渦度が，境界層外部のポテンシャル流の領域へ “貫入”する現象である．循環の保存則から，この“贯 入”は境界層内の流体自身之主流とが直接混合するて とによって初めて起とり得るあのである。すなおち， 境界層内の流れは物体表面加娳離しなりればならな い.つまり，流線は表面の層を離れて流体内に入って 行くことになる．境界䓥内では流れが剥離しないため 物体面汇沿う $x$ 万向の速度成分を $u$ ，とれに垂直な $y$ 方向の速度成分を $v$ とすると $v \ll u$ であるが, 流 れが划離するためには ひ〜uでなりればならない，し たがって剥離点は $v / u \sim 1 / \sqrt{R}$ から v/u〜1 へと $v$ が $\sqrt{R}$ 倍に不連続的に变化する特異点である ${ }^{1)}$ ．と の考え方にもとついて TELIONIS は㩆離点を定める基 
準を次のようにとっている゙2.

(1) 定常流の場合

(a) 静止壁

$$
\left.\frac{\partial u}{\partial y}\right|_{\text {wall }}=0 \text {, Prandtl's criterion }
$$

この場合の剝離点近傍の速度分布之流線とを模型的に 第1図江示す.

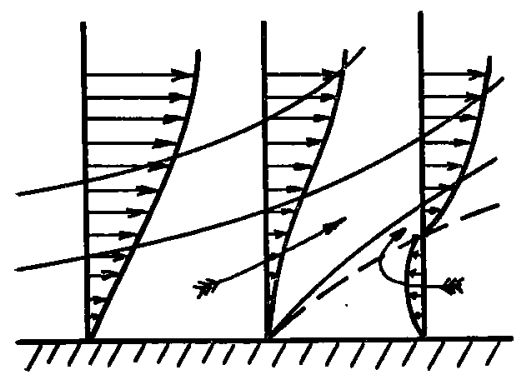

第 1 図 Prandtl's criterion (TEIIONIS')
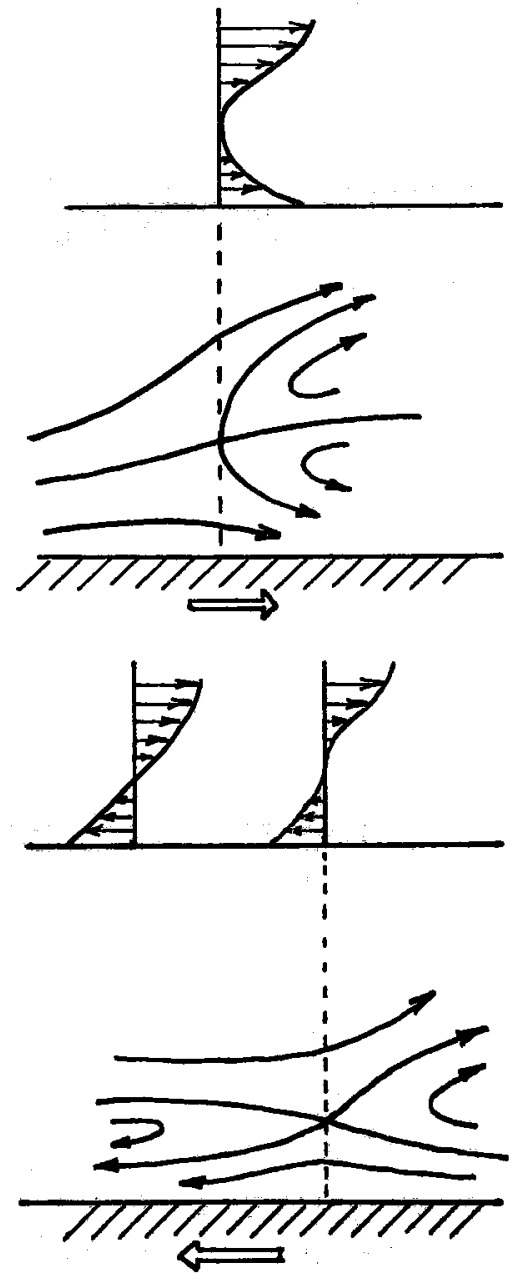

第2図 M.R.S. criterion (TELionis')

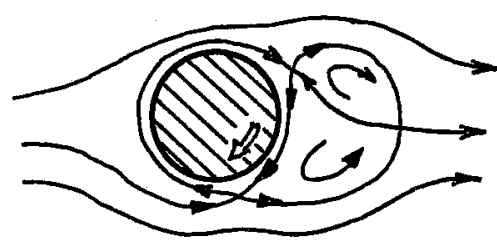

第3図一様流中の回転円柱 (TELIOUNIS ${ }^{21}$ )

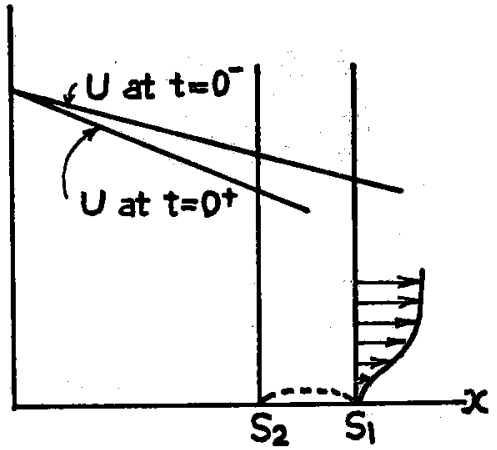

第 4 図 Sears' probllem (TeLionis's)

（b）運動壁

$u=\frac{\partial u}{\partial y}=0$, M. R.S. Criterion

この条件は MOORE, ROTT および SEARS によるも のであって，㓦離点は壁面上ではなくて流体中に現わ れる. それは，表面汇接して表面と同方向に運動する 流体の層が存在しなければならないからである．壁面 が主流と同方向および反対方向に運動する場合の流線 を模型的に第 2 図に示す．一様流中にこれに垂直に回 転円柱が置かれたとき，との2つの場合が同時に起と る.このときの流線の模型が第 3 困に示されている.

（2）非定常流の場合

$$
u=U_{s}(t), \quad \frac{\partial u}{\partial y}=0
$$

ここで Us $(t)$ は剝離点における速度を表わし，時間と とあに変る末知数である．例として Sears' problem の場合の流れを第 4 図倸す. Sears' problem は，主 流の下流方向の速度の変化方 $U_{\infty}=U_{0}\left(1-x / L_{1}\right)$ 加ら $U_{\infty}=U_{0}\left(1-x / L_{2}\right)$ 一之突然変わったときの剝離の問 題である. との場合あ, 剝離点は流体中に現われて, 第 4 図に示されるように， $S_{1}$ 加ら $S_{2}$ へと流体中を 移動する.

\section{2. 円柱を過ぎる流れの虽離と渦列}

$2.1 \boldsymbol{R}$ 数による流れの分類 一般に物体を過ぎる 流れが物体の両側の表面から剥離すると下流にいわゆ るカルマン渦列を形成する．との現象を，“物体の背 面の両側から交互に渦が ‘放出”されてカルマン渦列 


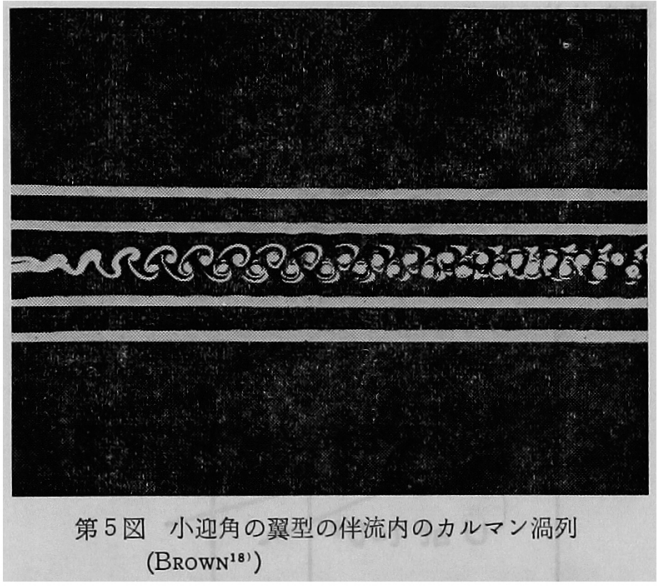

を形成する”と表現されることが多い，このため，剝 離とその結果の渦放出がカルマン渦列発生の必要条件 であるかのように詥解される場合があるが，剝離が起 てらなくてあ，互に平行な二つの的断層が接近して存 在し，かつ剪断層内の渦度の符号が逆であれば，カル マン渦列発生が可能である．例えば一様流中にこれと 平行に置加れた平板の場合，㔀離は起こらないのにそ の伴流にはカルマン瀜列が発生する3． また，小迎角 の翼型の場合す同様である. 第 5 㘡にその例を示す.

円柱の場合は，一般に剝離が起こり交互に渦が放出 される. 㔀離の起こる $R$ 数の下限は友近・宮城の計 算によれば 3 程度とされ，種子田 ${ }^{32}$ の実験によれば 5 程度である．円柱表面から㔀離した剪断層から渦列か 形成される現象については，MORKOVIN ${ }^{5)}$ が $R$ 数に よって分類しているが，乙こではそれと多少違った分 類をした.

(1) $R<3 \sim 5$ ，無渦領域 (No-vortex region) $R$ 数がこのように非常に低い場合円柱表面の流れは剝 離せず，表面で作られる渦度は流体中に広く抎散す る.

(2) $3 \sim 5<R<60 \sim 70$, 双子渦領域 (Twin-vortex region) 円柱表面の境界層が剝離してできた層流剪 断層はら旋状になって，ここに渦度の集中した領域を 形成，すなわち円柱背面に付着した双子洞を形成す る. $R<30 \sim 40$ では伴流は直線状であるが，乙れよ り大きい $R$ 数に対しては波状となる.

(3) $60 \sim 70<\boldsymbol{R}<150 \sim 300$, 純カルマン佩列領域 (Pure Karman-vortex region) 双子渦の強さと規 模が大きくなり，円柱背面に安定に付着していること ができなくなって，左右交互に放出されて下流の伴流 内に典型的ないわゆるカルマン渦列を形成する．現象 の過程を模型的に表わせば次のようになる.すなわ ち,

層流㔀離剪断層—渦度集中一一渦形成一一放出
一カルマン渦列

(4) $150 \sim 300<\boldsymbol{R}<6 \times 10^{3}$ ，垔臨界領域 I（Subcritical region I) 層流剥離した穷断層内で，その 不安定性のため微小㨨乱が発達して第 1 次の渦度集中 が起こり，小さい剪断層渦 (shear layer vortex) を 作る。この舅断層渦の列となった剪断層がら旋状にな って策 2 次の渦度集中が進み，剪断篔渦より一段大規 模な渦を形成する．との渦が交互に放出されてカルマ ン渦列となる (第 6 図).

層流剥離煎断層——不安定一一第 1 次渦度集中一 剪断層渦一一第 2 次渦度集中一一大きい渦——放出 一演列.

(5) $6 \times 10^{3}<\boldsymbol{R}<3.5 \times 10^{5}$, 亜臨界領域 II (Bubcritical region II) 層流弱離剪断層は，第 1 次渦度 集中を起こす前に乱流に僄移する，との乱流蒥断層内 に第 1 次渦度集中が起こって乱流の剪断層渦が形成さ れる.この乱流剪断層渦が集中して第 2 次渦度集中が 進みカルマン渦列を形成するようになる，との第 2 次 渦度集中の起こる場所は $R$ 数の低い場合よりずっと 下流になる(第 7 図)

層流剝離剪断層一一遷移一一乱流剪断層一一第 1 次

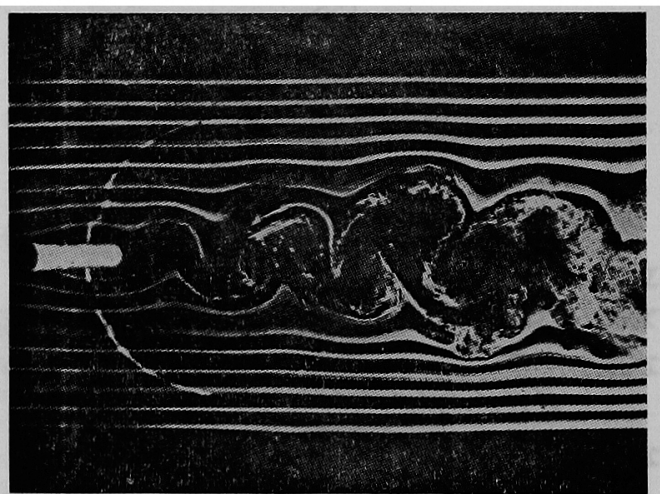

第6 図 剪断層渦からカルマン渦列の形成 $\left(\right.$ Brown $\left.{ }^{18}\right)$

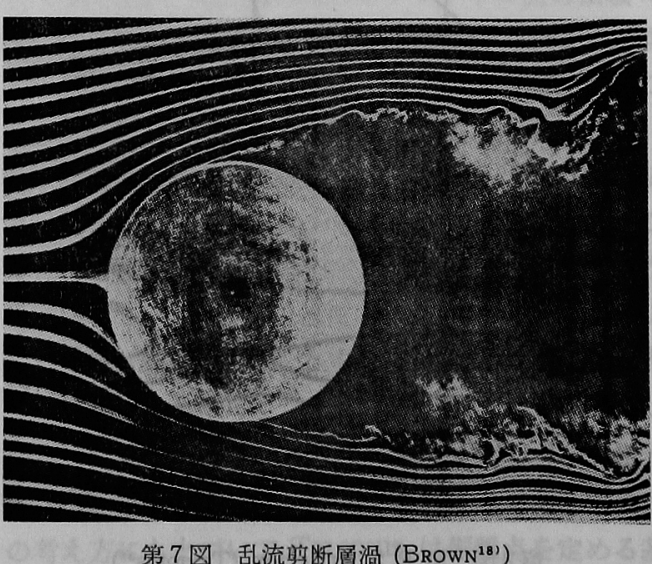


渦度集中一一第 2 次渦度集中一一渦列

(6) $R \approx 3.5 \times 10^{5}$, 臨界領域 (Critical region) よく知られているようにての $R$ 数のあたりで抵抗係 数が急激に減少する．その変化はほ上んよ゙不連続的で あることが谷 ${ }^{6)}$ によって示されている，抵抗減少の原 因は翗離泡が形成されることである，すなわち，円柱 表面の層流境界層が愿流剥離し，この層流剪断層が乱 流に遷移して円柱表面に再付着し，いわゆる㔀離泡を 形成する. 再付着した後の乱流境界層は，層流剥離点 よりずっと下流で再び剝離する。このため，円柱表面 の匠力分布は亚臨界領域での圧力分布よりあポテンシ アル流のそれに近くなり，抵抗が減少する、第8図に 西臨界( $\nabla$ 印)，臨界 ( $\triangle$ 印) および超臨界 (○印) の各 領域での圧力分布を示す．园中の个印は層流㔀離点を 示す. BEARMAN ${ }^{7}$ によれば臨界領域では剝離泡は円 柱の片側にのみ形成されている。これが両側に形成さ れると次に述べる超臨界状態となる。

円柱表面から剝離した蒥断層の再付着の結果，剝離 泡が形成されるこの現象が臨界的な現象であるため， この $R$ 数領域で現象が不連続的に変化するのである. 剝離剪断層が再付着したりしなかったりするとき，流 れは不安定で，はっきりした $S$ 数 (ストローハル数) は測定されない，剝離泡が形成されるか否かで $S$ 数

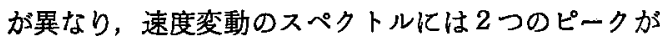
現われる7. HUMPHREYS ${ }^{8)}$ とよれば，流れは直径の 1. $4 \sim 1.7$ 倍の波長で軸方向に変化し細胞構造を示す. との場合の現象の過程は

層流剝離一一層流奠断層——遷移一一乱波剪断層 一一再付着 (不安定または非対称)一一乱流剝離—— 安定な渦列発生せず.

(7) $3.5 \times 10^{5}<\boldsymbol{R}<1.5 \times 10^{6}$, 超臨界領域 (Supercritical region) この領域では円柱の両側面に剶離 泡が安定に付着している

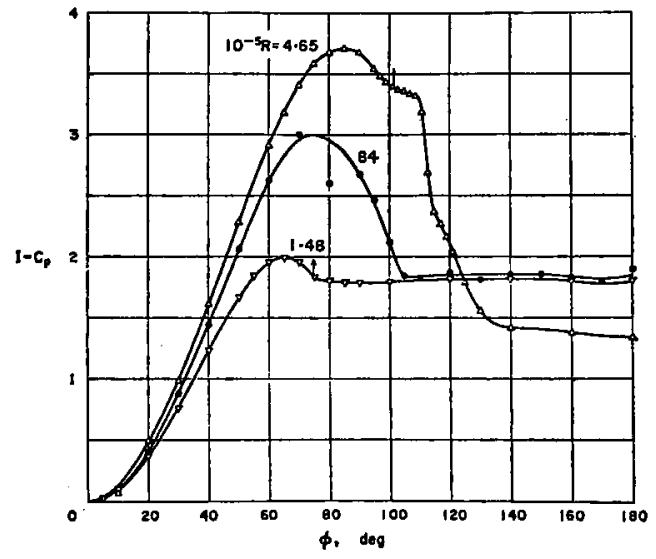

第 8 因 円柱表面の压力分布（谷“）
の $1.0 \sim 1.2$ に刘して 0.3 程度である. 一方， $S$ 数 は，亜臨界領域での約 0.2 に対して，0.46 程度に大 きくなる，速度変動のスペクトルは鋭く，はっきりし た渦列の存在を示している. 㔀離点は, 㙬臨界領域で 上流側よどみ点から測って $78^{\circ} \sim 94^{\circ}$ であったのに， この領域では約 $140^{\circ}$ と下流へ移っている ${ }^{9)} . R$ 数が $1.5 \times 10^{6}$ に達すると剔離点は再び上流側へ移動して 約 $120^{\circ}$ の位置に来る. この場合は次の遷臨界領域で ある. ての上限に近い $R$ 数になると, 速度変動スぺ クトルは拡がってピークは顕著でなくなる，それは外 部流れの乱れや棐面粗さのため，円柱表面の層流境界 層が局部的に乱流に榉移して，いわゆる乱流㗪を形成 することによるすのと思われる．乙の結果剝離泡が分 断されることが考えられる. HUMPHREYS は臨界領域 で軸方向に周期的な流れが現われる原因をこの乱流楔 によるむのと考えているようであるが，彼は划離泡の 存在に言及していないし，また臨界領域では㢦離以前 の境界層は未だ層流状態を保っているので，彼の考え には疑問の余地があると思われる.

この場合の過程は

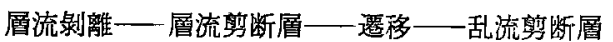

一一再付着 (両側に安定な剝離泡形成)——乱流境界層 -1 一乱流剝離——渦度集中一一渦列

(8) $\boldsymbol{R} \approx 1.5 \times 10^{6}$, 第 2 臨界領域 (The second critical region) ACHENBACH ${ }^{9)}$ の剥離点の測定結 果, BEARMAN ${ }^{7)}$ P DELANY \& SORENSEN ${ }^{10)} \sigma S$ 数 の測定結果によれば， $R \approx 1.5 \times 10^{6}$ に第 2 の臨界領域 が存在することが示唆されている. RoshKo ${ }^{11)}$ の抵抗 係数之 $S$ 数の測定もてれあ裏づけている. この領域 では，流れの $R$ 数による変化は，第 1 の臨界領域よ りあ緩徐である.それは，第 1 臨界領域では再付着が 流れの様子を左右する原因であったので，変化が急激 であったが，第 2 臨界領域では，剝離以前の境界層が 乱流に摡移するため剝離泡が消失するここにより，さ らにこの現象，すなわち層流境界層内に乱流班点が発 生し乱流楔を形成する現象は，時間的に平均すれば， $R$ 数の増加ととすに連続的に発達することによるから である. この領域で $S$ 数は一定とならず， 0.45 から 0.32 の範用にわたっている.

この場合の現象の過程は

層流境界層一一局部的遷移一一乱流楔発生（三次元 性)一一剝離泡分裂——渦列発生せず.

(9) $1.5 \times 10^{6}<\boldsymbol{R}$, 超々臨界領域 (Hypercritical region) $R$ 数を増加して行くと， $R \approx 3.5 \times 10^{5}$ あた りで抵抗係数が 1.2 から $0.3 へ ， S$ 数加 0.2 加ら 0.45 へと急激に変化することはよく知られていたが， さらに $R$ 数を増加すると， $R=3.5 \times 10^{6}$ で抵抗係数 
$0.7, S$ 数 0.27 が得られ，その後との值を保つこと が RosHKo ${ }^{111}$ によって示された. とのため従来の超 臨界領域の上にさらに新しい領域をつけ加えなければ ならないととになった. MORKOVIN ${ }^{5)}$ はこれを transcritical region (遷臨界領域) 乙四んでいるが，てれは 必ずしあ適切な名称とは思われず，むしろ hypercritical region（超々臨界領域）とであ呼んだ方がよいと 思われる. (ACHENBACH" は，従来の Supercrtical region Critical region, この新領域を Supercritical region と呼んでいる.)

この領域では，境界層はまず層流から乱流遷移し， この乱流境界層が $115^{\circ} \sim 120^{\circ}$.で剥離し，乱流の永離 尊断層の渦度集中が起こって，規則的な渦列を形成 し; そのため一定の $S$ 数 $(0.27)$ が測定される. 現象 の過程は

層流境界層一一遥移一一乱流境界層一一乱流㓦離 一一乱流剪断層一渦度集中一一渦列

抵抗係数 $C_{d}$ と $S$ 数の逆数 $1 / S$ とを $R$ 数に対し てプロットした RosHKo のグラフ ${ }^{11}$ を第 9 図に示し た. また㔀離点位置の $R$ 数以上る変化 ${ }^{99}$ を第 10 図に 示した. なお，各領域での流れの様子を模型的に第 11 四に示した.

2.2 三次元性 最後に，流れの軸方向の変化，す なわち三次元性について付け加わえる．とれには 3 種 類あると思われる.

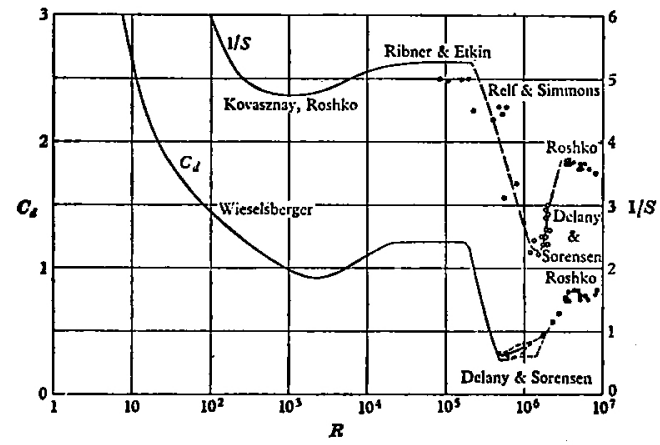

第 9 図 円柱の抵抗係数とストローハル数の逆 数の $R$ 数による変化 (RosHKo ${ }^{211}$ )

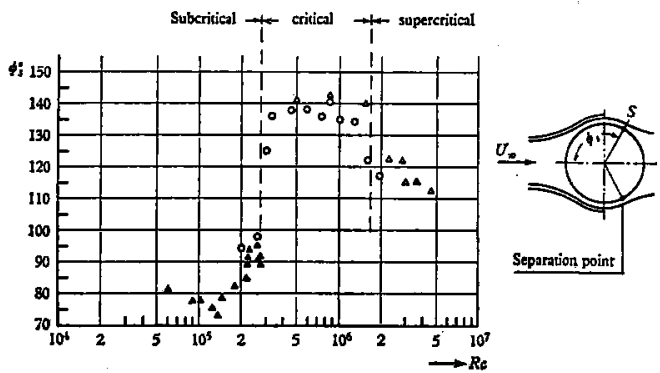

第 10 図虽雜角と $R$ 数 (ACHENBACH ${ }^{23}$ )
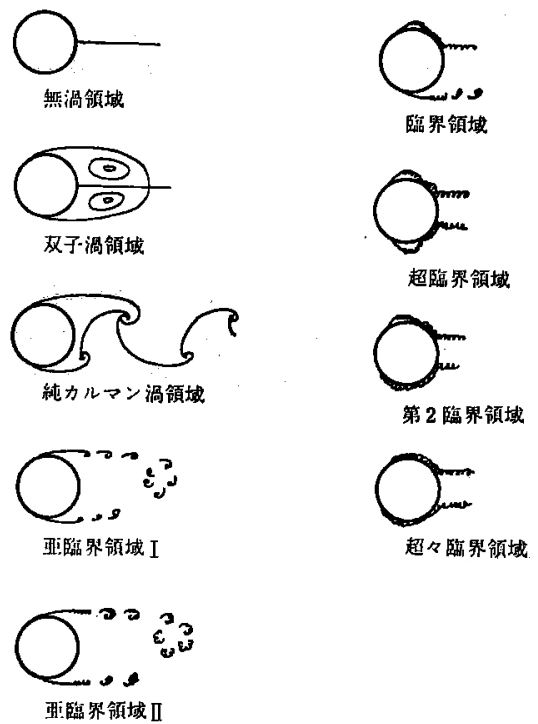

第 11 困 流れの模型図

第 1 は純カルマン渦列領域において GERRARD ${ }^{123} に$ よって観察されたあのである。これはカルマン渦の渦 線が円柱軸に平行でなくて平均して $14^{\circ}$ 程度傾いてい る場合である．乙のととは円柱表面加らの境界層㓦離 か，または剝離した剪断層内の渦度集中かが，軸任沿 って同時佂起こらずに，最初汇起こった点から両端へ と一定速度で伝播するととを示唆している，乙の現象 は GERRARD す指摘しているように流れの乱れによる あのと思われる。

第 2 は前述の HUMPHREYS や BEARMON によって 観察された臨界領域付近での細胞構造による三次元性 である.

第 3 は上流側腚み点付近加ら発生する GöRTLER 型 維渦による三次元性である 133，14)，15)，その模型を第 12 図に示す.このような縦渦が円柱表面境界層の遷移 およで娳離におよ沽す影響は未だ明らかでない。

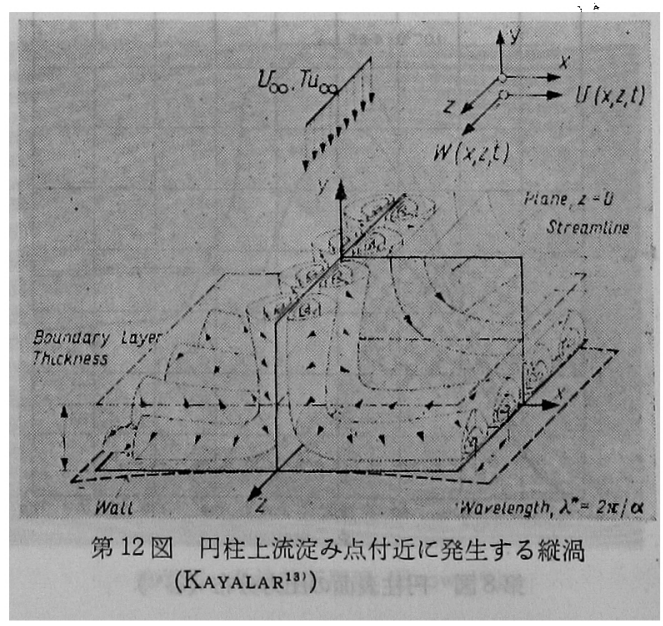


HAMA $^{16)}$ が観察したカルマン渦の三次元性は，この種 の縦渦に起因している可能性がある.

\section{3. 一様流中の回転円柱}

3.1 負揭力 一様な流れの中に，乙れと垂直に置 加れた回転円柱には，一様流の方向に垂直に揚力が働 くということは，Magnus effect としてよく知られて いる．乙の場合揚力は，円柱表面の速度が主流速度と 逆向きの側加同方向の側へ上作用する. しかし $R$ 数 が大きくて円柱回転数があまり大きくないときは揚力

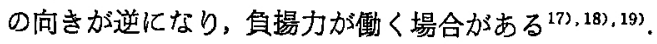
第 13 図に田中・永野の結果を示す。乙のように一様 流中の回転円柱の揚力は，翼型の場合のように簡単に は計算で求めることはできない，翼型のまわりの流れ が㔀離しない場合には，JoUKOWSKI の仮設によって 循環の大きさを求め, KUTTA-JOUKowsKI の定理によ って揚力を求めることができるが，回転円柱の場合に は，剝離して失速した後の翼型の揚力を求めるの之同 様で，円柱表面の境界層の剝離の様子が両㑡で異なっ ていてしかす容易俑知できず，したがって復環の大 きさあ揚力も求めるととが困難である，乙の意味で， BROWN $^{18)}$ の言うように，Magnus effect は円柱表面 の境界層が両側で非対称に剝離することに依ると言う ことができよう．との非対称刎離は，円柱の片侧では 外部流速度と表面速度が同方向であるので円柱表面近 傍の流体は表面に entrainされて剥離点が下流に移動 するが，反対側では逆に㔀離点が上流任移動するとと に上る. 一様流速度による $R$ 数加臨界 $R$ 数优近く て円柱回転数があまり大きくない場合，相対速度が小 さい側では, 淀み点功の距離でつくった境界層 $R$ 数

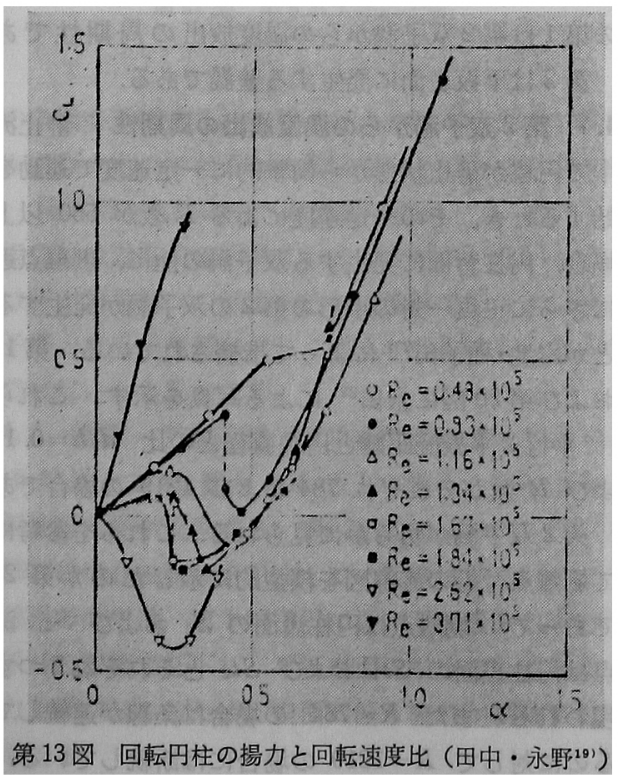

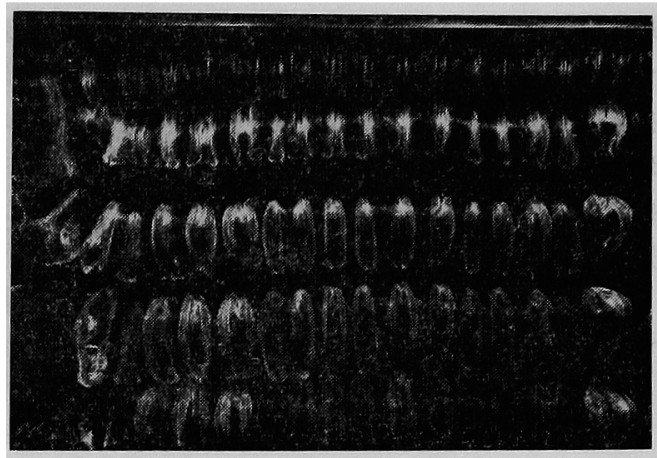

第 14 図 回転円柱の伴流

が小さいので境界層は層流のまま早期に剝離する、こ れに反して，相対速度の大きい側では，境界層 $R$ 数 が大きく，境界層は㓦離する前にまず乱流に僄移する ので，剝離点はずっと下流へ移動する．このため剝離 点の非対称性が前の場合と逆になり，揚力の向きが逆 転して負揚力を発生することになる．第 13 図て $R$ $=3.71 \times 10^{5}$ の場合負揚力が現われず大きい正揚力を 示しているのは，両側と屯乱流煣離をしていることに よるものであろうと思われる。

3.2 カルマン渦列と縦渦との連成した伴流 ${ }^{20), 211}$ $R$ 数が純カルマン渦列領域内にあって，回転円柱の表 面速度が一様流速度のほほ 2 倍以上になると，その伴 流には，第 14 図に示されるように，カルマン渦列の 各渦が円柱軸方向に顕著な周期性を示し，三次元性が

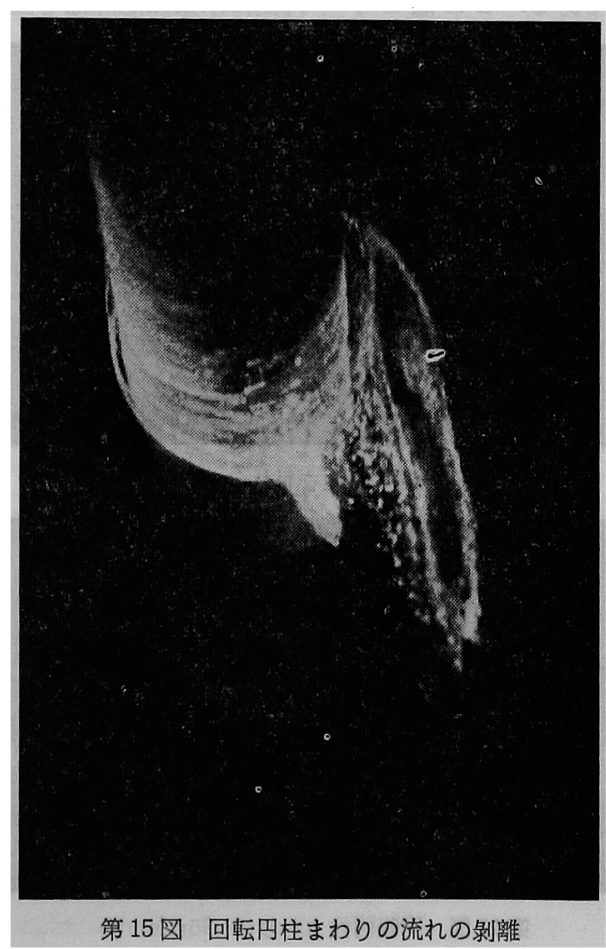


現われる．乙の場合問題が 2 つある. 第 1 は剥離に関 するあのである，すなわち，静止円柱の場合境界層が 表面から剥離することは明らかであるが，回転円柱の 場合，过り無しの条件を考える之き，境界層は同様に 表面から剥離するだろうかという疑問である．第 2 は 規則的な三次元性の原因は何かという問題である.

（a） カルマン渦列の形成 上記の第 1 の疑問に対 する答は，“剝離の基準”の項で述べたように，剶離 点は円柱表面ではなくて流れの中に現われるというこ とである. 第 15 図は， $U_{\infty}=3.1 \mathrm{~cm} / \mathrm{s}$ ，回転数 99 r. p. m., 円柱直径 $10 \mathrm{~mm}$ の場合, 円柱上流加ら水素 気泡を流したときの写真である，円柱表面から離れた 流体中に剥離点があるのが見られる，とのように㔀離 の様子は異なるが，剥離した結果カルマン渦列が形成 される点では，静止円柱の場合と同様である．水面の 流れは水中の流れとは異なっているので第 15 困は水 中の流れを示したあのである.

（b）円柱表面の境界層の二重構造 回転による円 柱表面の速度が一様流速度の 2 倍以上になると，円柱 表面近傍の流体は，円柱とともに回転するととにな る. この流体部分では，中心に近い方では円柱表面に entrain されて速度が大きく，中心から遠い部分は速 度が小さく Taylor 不安定によって Taylor 渦を発生 する可能性がある．実際，この部分では円柱を取りま く渦環が存在している. 第 16 図は第 15 図之同じ条件 でこの層の中に水素気泡発生導線を置いて得られた写 真である. この層のすぐ外側に水素気泡導線を置く

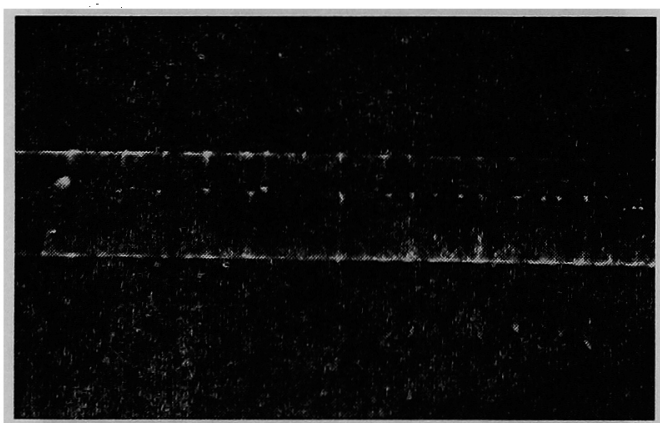

第 16 図 回転円柱まわりの Taylor 渦

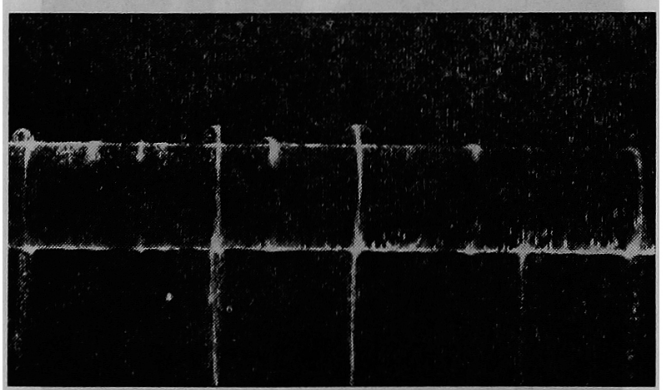

第 17 図 回転円柱まわりの Görtler 渦

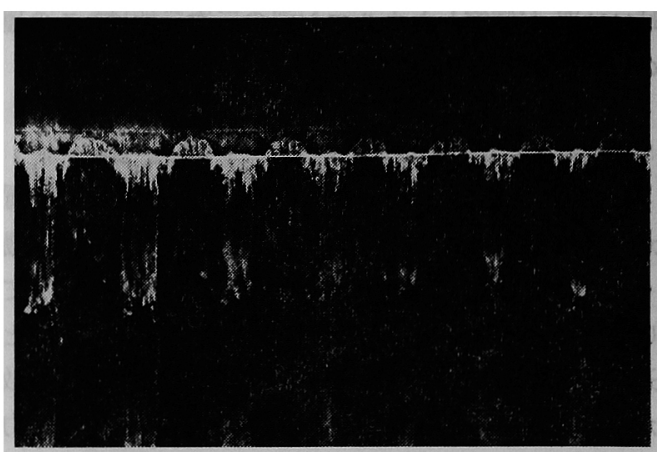

第18図 Görtler 渦と Kármán 渦との連成開始

と，第 17 図に見られるように，Taylor 渦とは別の正 負が対になった縦渦が大きいピッチで存在するととが わかる. との縱渦は， Taylor 渦とは墥って伴流へ流 れ出している. 水素気泡導線をさらに円柱の背面に置 くと，第 18 図に示されるように，乙の縦渦がカルマ ン渦と連成し始める様子が見られる，との䋛渦は，前 述の上流側淀み点付近加ら発生する Görtler 型渦であ ろうと思われる.

このような一様流中の回転円柱のまわりの流れは， 円柱にともなって回転する表面に接した層の中には Taylor 渦, その外側の剥離して下流へ流れる首の中 には Görtler 渦。さらに旼離した下流の伴流にはカル マン渦と, 3 種類の渦が同時に存在する特殊な場合で あると言うととができよう.

\section{4. 平行 2 平板間の円柱の非定常運動 22}

平行 2 平板の中央に置かれた円柱が，静止状態から 突然一定速度になったとき，円柱まわりの流体の非定 常運動について二，三の興味ある現象が観察される. その第 1 は第 2 双子渦からの渦度放出の周期性であ り，第 2 は平板表面澄生する壁渦である.

4.1 第 2 双子渦からの渦度放出の周期性 静止流 体中で円柱が静止状態から衝揫的に一定速度で運動を 開始するとき，その一定速度による $R$ 教が 550 以上 の場合，円柱背面に発生する双子渦の他に，剥離点近 傍にさらに正負一対の小形の第 2 の双子渦が発生する こ之が本地・種子田 ${ }^{23}$ によって指摘されている. 第 19 図および第 20 図に永田 ${ }^{22)}$ による写真を示す. これら は，平行 2 平板間距離と円柱直径との比 $d / h=0.11$ および $R$ 数がそれぞれ 784 および 1219 の場合であ る.第 2 双子渦が明らか们見られる.これらを参考に して剥離点付近の流線図を模型的に示したのが第 21 四であって，俅離点は円柱表面の $S_{1}$ お゙よび $S_{2}$ ，淀

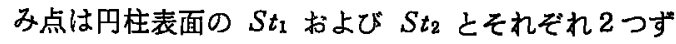
つ現われる. また $R=784$ の場合は条線が連続して いるのに対して $R=1219$ の場合には断続している. 


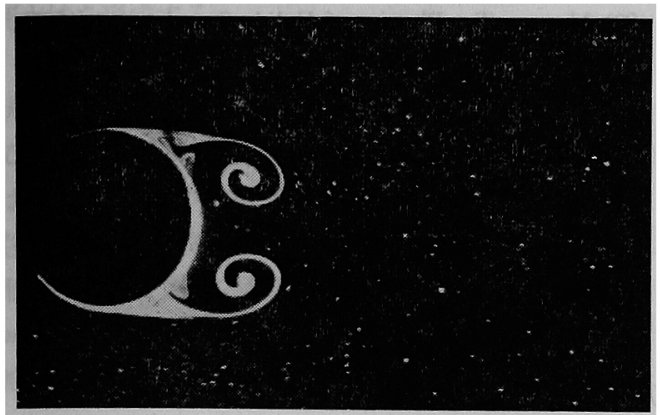

第 19 図 第 2 双子渦加双子渦への連続的渦度放出 $R=784, U t / d=2.07, d / h=0.11$ (永田 $\left.{ }^{22}\right)$

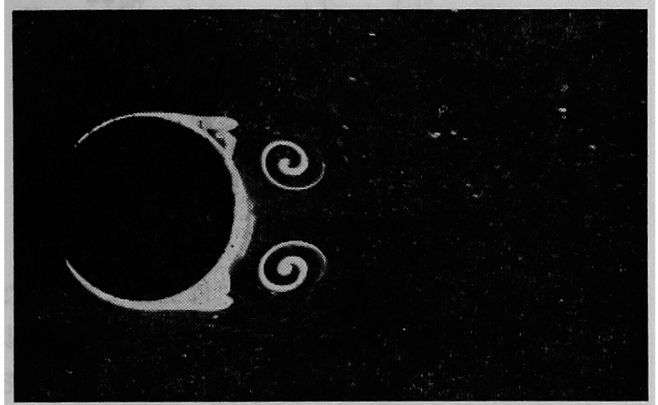

第 20 図 第 2 双子渦から双子渦への断続的渦度放出 $R=1219, U t / d=2.02, d i h=0.11\left(\right.$ 永田 $\left.{ }^{22}\right)$

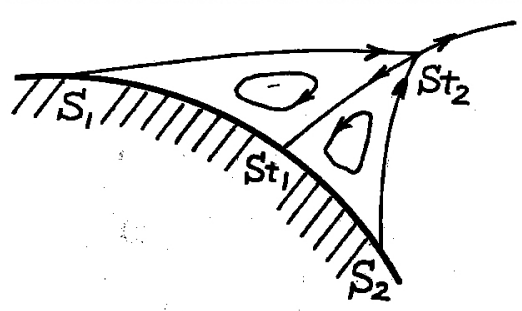

第 21 図 第 2 双子渦の流線

この条線を形成する流体粒子は上流の円柱表面の境界

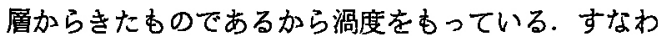
ち，境界層加ら流体中一の渦度放出加， $R$ 数加大き い場合には周期的に断続することが示されている．乙 れは第 1 双子渦への渦度供給の周期性であって，第 1 双子渦の放出の機構に対して何らかの端緒を与えるむ のではないかと思われる.

4.2 壁渦 円柱直径と 2 平板間の距離之の比 $d / h$ が 0.5 以上で. $R$ 数が 200 以上の場合, 円柱下流の 平板表面に渦が発生する，第 22 図は $d / h=0.63 ， R$ $=250$ の場合の流れを示す．この写真に見られるよう な壁渦の発生は，第 1 双子渦に近い平板表面の王力が 双子渦の影響で低下し，平板表面沿うて下流方向へ 王力上昇が起こるため，表面に沿う流れが凖離すると とに伡る。

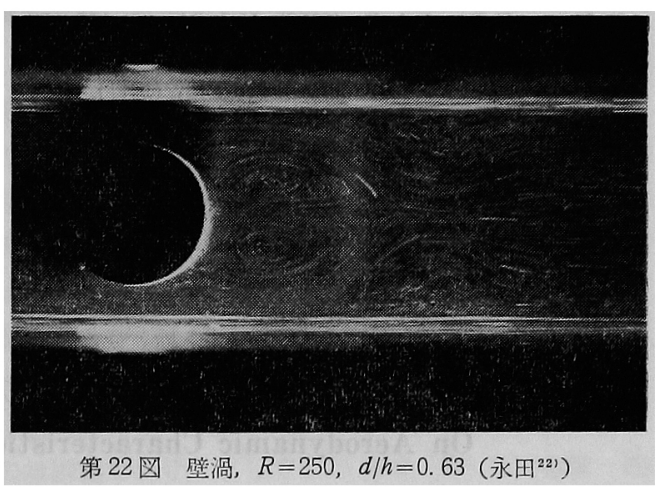

\section{4. むすび}

円柱を過ぎる流れにおいて，円柱表面の境界層の剝 離がいかに決定的な要因であるかについて概説してき た. 一方，それにあ拘わらず，剥離という現象につい ては末解決の問題が多く残されている. 例えば，㔀離 剪断流が捲き込んで双子瀜を形成する過程, 剴離剪断 流が再付着する機構，回転円柱の場合の上うな運動壁 からの㓦離，あるいは第 2 双子渦関連して非定常流 の剥離などはその代表的なあのであろう.

今回の剝離流シンポジゥムをきっかけとして剝離の 研究が一層盛んになることを期待する次第である.

\section{参考文献}

1) Landau, L. D. and Lifshitz, E. M. : Fluid Mechanics (1959), Pergamon Press, p. 151.

2) Telionis, D. P.: Boundary Layer Separation(1970), Ph. D. Thesis, Cornell Univ.

3) Tомотika, S. and Miyagr, T.: (1962), Memoirs of the College of Scinece, Univ. of Kyto, Series $A$, Vol. XXX. No. 1.

4) Taneda S.: J. Phys. Soc. Japan (1956), vol. 11, pp. 302-307.

5) Morkovin, M. V.: Pro. Symposiium on Fully Separated Flows (1964), pp. 102-118.

6) TANI, I.: Progress in Aeronautical Scieces, Vol. 5 (1964), Pergamon Press, pp. 70-103.

7) Bearman, P.W.: J.F.M. (1969), vol. 37, pp. 577585.

8) Humphreys, J.S.: J.F. M. (1960), Vol. 9, pp. 603612.

9) Achenbach, E.: J.F.M. (1968), Vol. 34, pp. 625639.

10) Delany, N. K. and Sorensen, N. E.: (1953) NACA T.N. No. 3038.

11) Roshro, A. : J.F. M. (1961), Vol. 10, pp. 345-356.

12) Grrrard, J.H.: J.F.M. (1966), Vol. 25, pp. 143164.

13) Kayalar, L.: Forsch. Ing-Wes. (1969), Vol. 35, pp. 157-167.

14) Kestin, J. and Wood, R.T.: J.F.M. (1970), Vol. 44, pp. 461-479.

15) Colak-Antic, P. and Hassler, H. : DFVLR-Nachrichten (1971), Heft 5, pp. 184-186. 
16) HAMA, F. R.: J. A. R. (1957), Vol. 24, pp. 156-158.

17) 谷 一郎: 科学 (1950), Vol. 20, pp. 405-409.

18) Brown, T. N. B. : See The Wind Blow (1971), Uuiv. of Notre Dame,

19）田中英穗，永野進：日本機械学会論文集 (1972), Vol. 38, pp. $1343-1352$.
20) Matsur, T.: Physics of Fulids Supplement (1967), S305.

21）松井辰彌，永田 拓：日本物理学会第22回年会予稿集 (1967), 4aN10.

22）永田拓他：日本機珹学会講演論文集 (1972), No. 723$2, \mathrm{p} .61$.

\section{Bluff Body の空力特性と後流* \\ On Aerodynamic Characteristics and Wake Flows of Bluff Bodies}

中

博**

Hiroshi NaKaguchI

\section{1. まえがき}

Bluff body の空力特性およびそのまわりの流れは, 流体力学の最も古典的な問題であると同時に，完全な 解明が最も困難な問題の一つでもある．航空宇宙の分 野では巨大なロケットに対する地上および低空での風 の影響に関連して，土木建築の分野では高層建造物に およ汸す風の影響问関連して，また船船や陸上交通機 械の高速化化伴い走行性能や振動，騒音に関連してそ れらの分野であ，bluff body の空気力学に新たな関心 が向けられれている.こてでは，二次元物体のまわり の低速の流机について，Reynolds 数があまり小さく ない範囲に限定して，乙れまでの研究を概観し，われ われの研究室での経験を参照しながら，問題点のいく つかを述べようと思う。

\section{2. 記 号}

$C_{D}$ : 抗力係数.

$C_{L}$ : 揚力係数.

$C_{p b}$ : 背王係数, $2\left(p_{b}-p_{\infty}\right) / \rho U^{2}$.

$h$ : bluff body $の$ 寸法, 一㥞流に垂直な高さ.

$n:$ 単位時間内に吐き出される渦対の数.

$p_{\infty}:$ 一様流の静圧.

$p_{b}$ : 背圧.

$R e$ : Reynolds 数, Uh/ע.

$S$ : Strouhal 数, $n h / U$

$U:$ 一様流の速度.

$U_{s}:$ 自由流線上の速度.

$\rho:$ 流体の密度.

$\nu:$ 動粘性係数.

* 昭和 47 年 4 月 6 日日本航空宇宙学会「剔離流シンポジ ウム」で講演 昭和 47 年 9 月 5 日原稿受理

** 東京大学工学部

\section{Bluff body のまわりの流れと 空力特性の概要}

$R e$ が 40 程度以上の円柱, 流れに垂直に置かれた 平板，矩形柱など bluff body のまわりの流れは，少 なくとも概念的にはよく知られており，それは扣よそ 次のように要約される.

(1) bluff body は下流に幅広い wake を伴い， 流体加受ける時間平均的な抗力は非常に大きい（第 1 図).

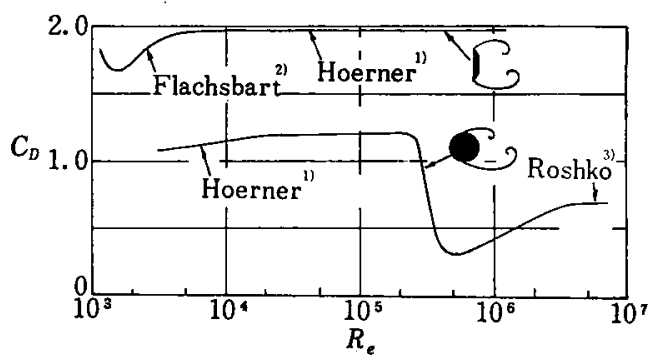

第 1 図 Bluff body の抗力係数とレイノルズ数 (円柱之平板).

（2）物体の直ぐ下流側にできる剝離域では，王力 が場所によってあまり変化せず，背圧係数 $C_{p b}$ は負の 大きい值を示し(第 2 図)，乙の部分の流体は丰効的に

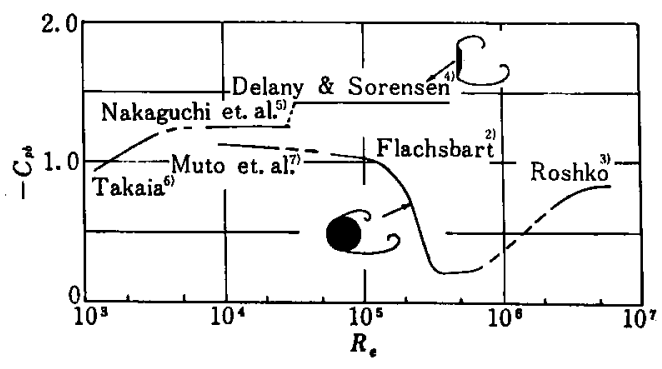

第 2 図 Bluff body の背圧係数とレイノルズ数 (円柱と平板). 